\title{
PASSALUS COARCTATUS PERCHERON, 1835 (COLEOPTERA: PASSALIDAE): REDESCRIPTION AND NEW DISTRIBUTIONAL RECORDS
}

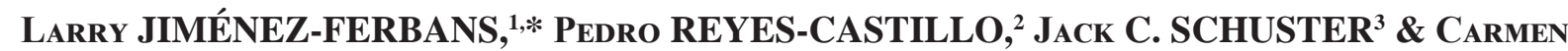 \\ UPEGUI-VÉLEZ ${ }^{4}$
}

\begin{abstract}
${ }^{1}$ Grupo de Investigación Evolución, Sistemática y Ecología Molecular. Facultad de Ciencias Básicas. Universidad del Magdalena, Carrera 32 No 22 - 08, Santa Marta, Colombia P.C. 470004.

${ }^{2}$ Instituto de Ecología, A.C. Carretera antigua a Coatepec 351, El Haya, Xalapa, Veracruz, México; <pedro.reyes@inecol.mx>

${ }^{3}$ Universidad del Valle de Guatemala, Apartado Postal 82, 01901, Guatemala, Guatemala; <jschuste@uvg.edu.gt>

${ }^{4}$ Cr. 63 \# 22 - 45 Apto 903 Torre 2, Parque Central Ciudad Salitre, Bogotá D.C., Colombia; <entomopaisanita@gmail.com>

*Autor corresponsal: <larryjimenezferbans@gmail.com>
\end{abstract}

Recibido: 29/02/2016; aceptado: 27/05/2016

Jiménez-Ferbans, L., Reyes-Castillo, P., Schuster, J. C. \& UpeguiVélez, C. 2016. Passalus coarctatus Percheron, 1835 (Coleoptera: Passalidae): redescription and new distributional records. Acta Zoológica Mexicana (n. s.), 32(2): 168-173.

ABSTRACT. Passalus (Passalus) coarctatus Percheron, 1835 was described from Brazil without precise locality data; except for its inclusion in catalogues, nothing is known of this species and only one publication has provided specific locality data. We provide precise localities for $P$. coarctatus in Trinidad and Tobago, Venezuela, Brazil and Bolivia, we describe the third instar larva, discuss its taxonomic status and correct errors of previous publications.

Key words: Coleoptera, larval diagnosis, key to species, geographic distribution.

\section{INTRODUCTION}

In the catalogue of Hincks and Dibb (1935: 56) Passalus coarctatus Percheron is included in Section III "Neleus" of the subgenus Passalus s. str., Brazil is noted as the country from which it was described and is considered a valid species as did Percheron (1841: 12), Luederwaldt (1931: 185), Blackwelder (1944) and Fonseca \& Reyes-Castillo (2004). However, Burmeister (1847: 483) considered $P$. coarctatus synonymous with $P$. coniferus Eschscholtz, 1829, a synonymy accepted by Gemminger \& Harold (1868) and Kaup (1871: 86). Nevertheless, Kuwert (1898: 271) designated it an aberration of P. suturalis Burmeister.

None of these authors added information to the original description, nor mentioned new key characters, precise localities or added figures of $P$. coarctatus, which suggests that they had not examined specimens. It seems like the interpretations of Burmeister (1847) and Lue-
Jiménez-Ferbans, L., Reyes-Castillo, P., Schuster, J. C. \& UpeguiVélez, C. 2016. Passalus coarctatus Percheron, 1835 (Coleoptera: Passalidae): redescripción y nuevos registros distributivos. Acta Zoológica Mexicana (n. s.), 32(2): 168-173.

RESUMEN. Passalus (Passalus) coarctatus Percheron, 1835 fue descrita de Brasil sin datos precisos de localidad; exceptuando su inclusión en catálogos, no se conoce nada de esta especie y solo un trabajo publicado ha suministrado registros específicos de localidad. Proporcionamos localidades precisas para $P$. coarctatus en Trinidad y Tobago, Venezuela, Brasil y Bolivia, describimos la larva de tercer estadio, discutimos su estatus taxonómico y enmendamos errores de publicaciones anteriores.

Palabras Clave: Coleoptera, Passalidae, diagnosis larva, clave de especies, distribución geográfica.

derwaldt (1931) were base on the description and figure of Percheron (1835: 49-51 Pl. 3, fig. 7), while it is possible that Kuwert (1898) based his interpretation only on the figure. Jiménez-Ferbans et al. (2015) cited P. coarctatus from Trinidad and Tobago, providing a short diagnosis and commenting the similarity of this species with P. unicornis LePeletier \& Serville, 1825. Recently, we found specimens coinciding with the original description of $P$. coarctatus. The purposes of this publication are to redescribe the adult and larva of $P$. coarctatus, provide precise new localities for the species, include a key for identifying it from related species and discuss nomenclatural aspects.

\section{MATERIALS AND METHODS}

The terminology employed is that of Boucher (2005) for the adult and that of Schuster \& Reyes-Castillo (1981) for 
the larva. The specimens are deposited in the following collections: Colección de Artrópodos de la Universidad del Valle de Guatemala, Guatemala (UVGC); Colección Entomológica del Instituto de Ecología A. C., México (IEXA); Insect Collection of The Field Museum of Chicago (FMNH), Instituto Nacional de Pesquisas da Amazonia (INPA) and Museo del Instituto de Zoología Agrícola Francisco Fernández Yépez, Universidad Central de Venezuela, Venezuela (MIZA). In the section on "Material examined", at the end of the collection data in parentheses is the number of specimens, occasionally the gender, and the acronym of the collection where deposited.

\section{RESULTS}

\section{Passalus (Passalus) coarctatus Percheron, 1835}

(Figs. 1, 5-9)

Diagnosis. 34.0-38.3 mm long. Clypeus hidden below the frons, with anterior angles developed. Secondary mediofrontal tubercles on anterior edge of frons separated by a distance less than the distance between them and the mediofrontal tubercles. Mediofrontal tubercles (MT) developed, on the outer side of the base of MT are located the internal tubercles, that are small. Central tubercle long, with free apex (Figure 1), reaching the anterior edge of

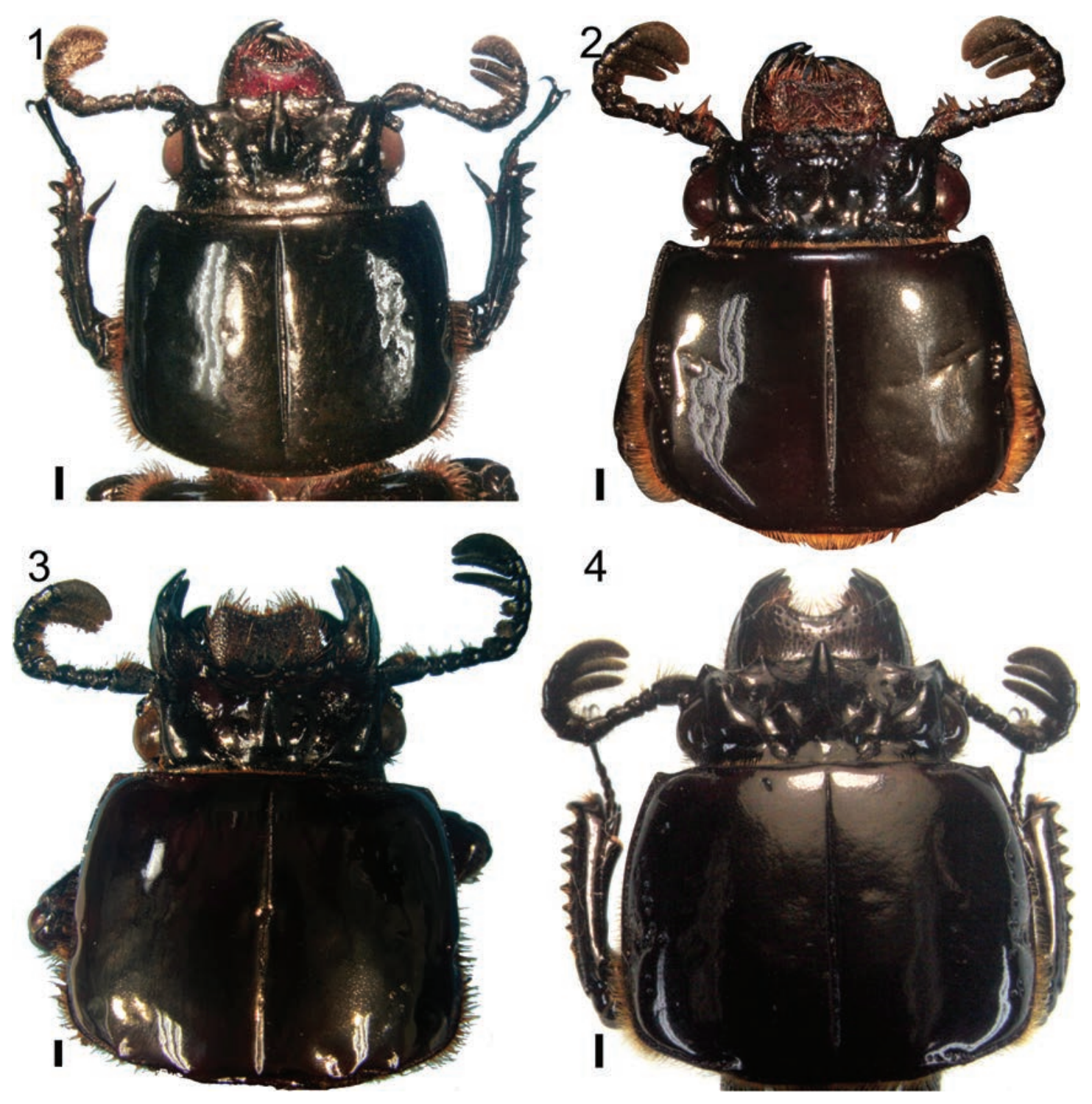

Figures 1-4. Head and pronotum, dorsal view. 1 Passalus coarctatus. 2 P. coniferus. 3 P. interruptus. 4 P. unicornis. Scale bars: 1 mm [Photos by L. Jiménez-Ferbans]. 


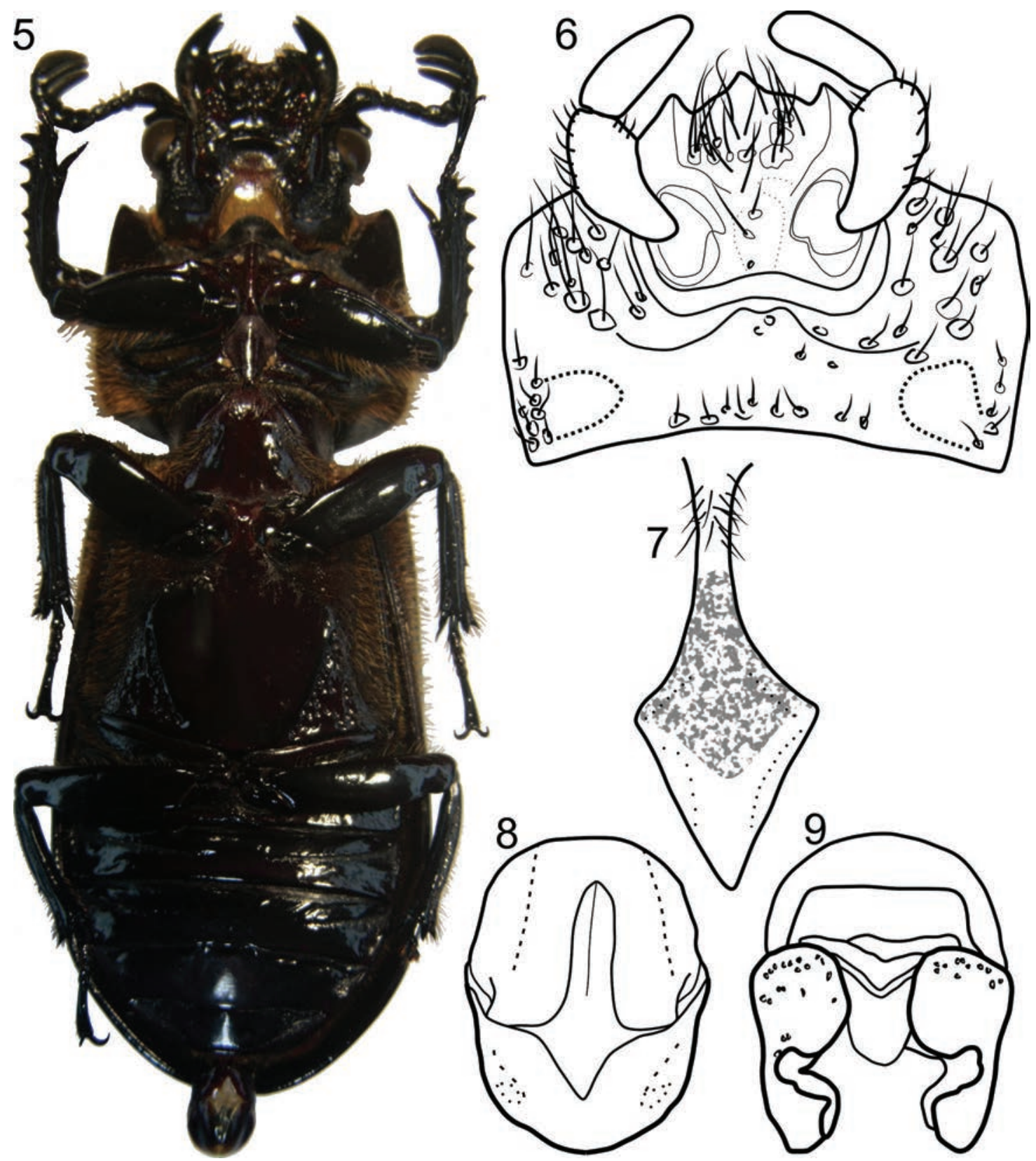

Figures 5-9. Passalus coarctatus. 5 Habitus, ventral view [Photo by L. Jiménez-Ferbans]. 6 Prementum and mentum, ventral view. 7 Proesternelum, ventral view. 8 Edeagus, ventral view. 9 Edeagus, dorsal view [modified from Upegui-Vélez 2008].

frons; postero-lateral tubercles large and marked. Antennal club with three elongated lamellae. Apex of lacinia bidentate. Median basal region of mentum pubescent and protruding (Fig. 6). Prosternal process rhomboidal. Pronotal arms shiny and pubescent. Mesosternum laterally pubescent (Fig. 5), with mesosternum scars well-defined and pubescent. Metasternum sides almost fully pubescent, including latera fossae; metasternal disc delimited entirely by punctate area. Humeri fully pubescent; epipleura pubescent in basal 2/3.

Redescription. Head (Fig. 1): labrum with lateral edges slightly arched and frontal border concave. Anterior edge of frons with secondary mediofrontal tubercles and mediofrontal tubercles (MT) projected forward, both are of equal length; internal tubercles very marked, located close to MT. Central tubercle thick, sharpened forward, 
slightly arched and reaching the anterior border of the head. Frontal area punctate on anterior third; laterofrontal tubercles slightly developed; frontal fossae punctate and glabrous; ocular canthus with scarce setae. Antennal club with three slender and elongated lamellae (Fig. 6). Mentum with lateral fossae glabrous, deep and sub-circular (Fig. 6); median basal region of mentum protruding and pubescent on posterior part.

Thorax. Pronotum quadrangular, glabrous, with anterior angles slightly acute and sides with scarce punctures close to lateral fossae; marginal groove narrow on anterior margin, occupying 1/3 of pronotum anterior border. Prosternal process rhomboidal, with apex shiny (Fig. 7). Mesosternum punctuate and pubescent laterally; mesosternum scar oval well-defined, punctuate and densely pubescent. Posterior angle of mesepisternum and mesepimeron pubescent. Metasternal disc fully delimited by punctate area. Lateroanterior metasternum punctate and pubescent. Metasternal fossae pubescent, wider than tibiae II.

Elytra. Shiny, anterior border rectangular and pubescent; humeri fully pubescent; epipleura pubescent until the level of the first abdominal tergite; elytral striae with marked rounded punctures in lateral striae and weak rounded punctures in dorsal striae.

Legs. Anterior ventral border of profemur with pronounced and complete groove; tibia I with dorsal groove; tibiae II with a small lateral spine, and tibiae III without lateral spines.

Aedeagus (Figures 8-9). In ventral view, basal piece fully fused to parameres; lateral lobes fused in V-shape; median lobe strongly sclerotized, globose, being $2 / 3$ of total length of aedeagus.

Redescription of the third instar larva. 1 specimen. TRINIDAD: Arima Valley, $580 \mathrm{~m}$ alt., 19 XII 81, JC Schuster, 1III 6.3, \#TT-18 (identified as Passalus unicornis Lepeletier et Serville by Schuster 1982). It possesses the typical setal pattern of Passalini and of the subgenus Passalus section "Neleus" (see Schuster \& Reyes-Castillo 1981), lacking the lateral shield setae of the pronotum, the lateral mesonotal setae, the lateral metanotal setae and all the abdominal setae save in the ninth sternite which presents one abdominal seta. The internal coxae have only one seta. Two medial tergal setae and two submedial tergal setae are on sternites 1-9. The anal ring on segment 10 is composed of ten setae.

Material examined. 27 adults and one larva. BOLIVIA: Beni Prov.; VII-26-VIII-4-1960; leg. B. Malkin// Chacobo Indian Village on Rio Benicito $66^{\circ}-12^{\circ} 20^{\prime}$ // Passalus
(P.) coniferus Eschsch. Det: J. Schuster 2001 // Passalus (Passalus) coarctatus Percheron Det.: Jiménez-Ferbans, 2015 (1 FMNH). Santa Cruz, 5 km SSE Buena Vista, Hotel Flora y Fauna, 11.ii.2007, CW LB O’Brien (1 UVGC). BRASIL: Acre: Manoel Urbano, Ramal 1, Sr. Altemiro, 8 54'29,7” S, 69¹5'”12,1”W/ 27-30.IX.2010, CRV Fonseca, FBP Gouveia, José Vicente e Plinio (INPA)/ P. coniferus/ Passalus (Passalus) coarctatus Percheron Det.: Jiménez-Ferbans, 2013 (1 INPA); Ramal 2, Ramal do km 20 90’9,2” S, 6849’15,7’W / 27-30.IX.2010, CRV Fonseca, FBP Gouveia, José Vicente e Plinio (INPA)/ P. unicornis/ Passalus (Passalus) coarctatus Percheron Det.: Jiménez-Ferbans, 2013 (2 INPA). TRINIDAD AND TOBAGO: Trinidad: Anima Valley, Log 7'’dia., 580 m, 19.XII.1981, J.C. Schuster. Passalus unicornis// Passalus (Passalus) coarctatus Percheron, 1835 Det.: Jiménez-Ferbans, 2012 (2, larva III UVGC); St. Andrew County, 2,5 mi. E of Valencia, ex. Large (very hard) logs on ground, 27.III.1987, coll. P. Hunter, W.T. Atyeo, Passalus (Passalus) unicornis Lep. et Serv. Reyes-Castillo, det. 87 // Passalus (Passalus) coarctatus Percheron, 1835 Det.: Jiménez-Ferbans, 2012 (1우 10 IEXA); George County mountains, $7 \mathrm{mi}$. N Port of Spain, ex decaying log, 26.III.1987, coll: P. Hunter, W.T. Atyeo. Passalus (Passalus) unicornis Lep. et Serv. Reyes-Castillo, det. 87 // Passalus (Passalus) coarctatus Percheron, 1835 Det.: Jiménez-Ferbans, 2012 (2ㅇ, 2 $\precsim$ IEXA). VENEZUELA: Bolívar: El Bochinche, R. Forestal Imataca, 200 m, 6-13XII-1974, Expedición Instituto Zoología Agrícola-Fac. Agronomía-UCV, (2 MIZA). Carret. El Dorado - Sta Elena, Km 88, 100 m, 26-IX-1967, L. J. Joly, (2 MIZA); same data as anterior, Joly \& Ramírez (5 MIZA). El Dorado Santa Elena Km 38, 160m, 31-VIII-1957, F. Fernández Y. \& C. J. Rosales (1 MIZA); same data as anterior, 23VIII-1957 (1 MIZA). Carret. El Dorado - Sta Elena, Km 88, 100 m, 28-IX-1967, J. L. García, Joly \& Ramírez/ det. Passalus unicornis (4 MIZA).

Distribution. Bolivia, Brasil, Venezuela (Upegui Vélez, 2008), and Trinidad and Tobago.

Key to Passalus (Passalus) coarctatus and related species (In part Upegui Vélez, 2008)

1. Mesosternal fossa pubescent. ............. 2

- Mesosternal fossa glabrous or with only 1-3 setae. . . .3

2. Central tubercle with apex very free, reaching the anterior cephalic border (Figure 1) (length 33-38 $\mathrm{mm}) . . . \ldots \ldots$...... Passalus coarctatus Percheron - Central tubercle with apex not free or barely free (Figure 2) (length 34-39 mm) ...Passalus coniferus Eschscholtz 
3. Marginal groove of last abdominal sternite incomplete. Large (length 44-50 mm) (Figure 3) .............. Passalus interruptus (Linnaeus) - Marginal groove of last abdominal sternite complete. Medium to large body................... 4 4. Pronotum pubescent on lateral fossa. Elytral striae 8-10 pubescent on total length $(36-45 \mathrm{~mm}$ ) (Figure 4) . . . . . . . . Passalus unicornis LePeletier \& Serville - Pronotum glabrous on lateral fossa. Stria 10 pubescent only on basal third. .................. 5 5. Central tubercle with apex free, curved upward in lateral view (29-32 mm). . . Passalus elfriedae Luederwaldt - Central tubercle with apex free and not curved upward in lateral view ..........Passalus suturalis Burmeister

\section{DISCUSSION}

In Burmeister (1847), where he considers $P$. coarctatus synonymous with $P$. coniferus, the author doesn't really discuss this decision nor mention the large central tubercle that distinguishes $P$. coarctatus. Percheron (1835), on describing the species, indicates that the central tubercle is exceptionally long; nevertheless, in the figure he cites, the tubercle is barely free. Probably this motivated his idea that $P$. coarctatus was a synonym of $P$. coniferus, criterion followed by Kaup (1871), who indicated that a variation existed within $P$. coniferus with respect to the length of the central tubercle. This variation was presumably due to Kaup's consideration of $P$. coarctatus, with a long, free tubercle, synonymous with $P$. coniferus, that has a shorter, reduced tubercle.

Burmeister (1847) synonymy is also followed in the catalogue of Gemminger \& Harold (1868), but they probably did not examine specimens and only accepted the proposal of Burmeister. Kuwert (1898), however, included it as an aberration of Passalus suturalis Burmeister, 1847. Nevertheless, Hincks \& Dibb (1935) indicate that Passalus suturalis sensu Kuwert is, in reality, a synonym of $P$. punctiger and recognized $P$. coarctatus as a valid entity, as did Luederwaldt (1931), which was similar to $P$. elfriedae. It is probable that the confusion concerning the status of $P$. coarctatus is due to, apart from the type series, no other specimens of this species were known and none of the authors mentioned clearly states that they had examined specimens. Instead, Figure 1 contrasts the morphology of the head of $P$. coarctatus with other species of Passalus; it is without doubt that it is a separate species, easily recognized by its long horn and poorly raised dor- sal ridges. For these reasons, the synonymies proposed for $P$. coarctatus should not be accepted.

Passalus coarctatus presents a distribution to the north and center of South America, in the Guyana-Amazon shield, although its range will probably expand to others countries (v.g. Colombia) when misidentified material from other collections is examined. In fact, almost all the specimens we examined were determined as Passalus unicornis, a species that also possesses a long horn. In $P$. unicornis the mentum and the mesosternal scars are glabrous and elytral striae 8-10 are pubsecent to their ends, characters which differentiate it from $P$. coarctatus.

Also, Schuster (1992) cited the same larva that we examined, assuming it to be $P$. unicornis, determination hereby corrected: the larva corresponding to P. unicornis in Schuster (1992) is an instar II; the instar III larva mentioned is, in reality, P. coarctatus.

ACKNOWLEDGEMENTS. We thank Dolores González for criticizing the manuscript and Efraín de Luna of the Laboratorio de Morfometría, Instituto de Ecología A.C., for permitting photography of specimens. We also thank the curators Crystal A. Maier (FMNH) and Claudio R.V. da Fonseca (INPA) for assistance provided during visits to their collections. This work was financed by CONACYT-México, through Project 169604.

\section{REFERENCES CITED}

Blackwelder, R. E. 1944. Checklist of the coleopterous insects of Mexico, Central America, the West Indies, \& South America. Part 2. Bulletin United States National Museum, 185: 189-341.

Boucher, S. 2005. Évolution et phylogénie des coléoptères Passalidae (Scarabaeoidea) Les taxons du groupe famille la tribu néotropicale des Proculini et son complexe Veturius. Annales de la Société Entomologique de France, 41: 239-603.

Burmeister, H. 1847. Handbuch der Entomologie. Vol. 5, Coleoptera Lamellicornia Xylophila et Pectinicornia. Berlin, C.F. Enslin, 584 pp.

Fonseca, C.R.V. \& Reyes-Castillo, P. 2004. Synopsis on Passalidae family (Coleoptera: Scarabaeoidea) of Brazil with description of a new species of Veturius Kaup, 1871. Zootaxa, 789: 1-26.

Gemminger, M. \& Harold, B. 1868. Catalogus Coleopterorum hucusque descriptorum synonyralcus et systematicus, 3 : 753-978. Monachii.

Hincks, W. D. \& Dibb, J. R.1935. Pars 142 Passalidae, pp. 1-142. In: W. Junk (Ed.). Coleopterorum Catalogus. S. Schenkling. The Hague.

Jiménez-Ferbans, L., Reyes-Castillo, P. \& Schuster, J. C. 2015. Passalidae (Coleoptera: Scarabaeoidea) of the Greater and Lesser Antilles. Zootaxa, 3956: 491-512.

Kaup, J. J. 1871. Monographie der Passaliden. Berliner Entomologische Zeitschrift, 15: 1-125. 
Kuwert, A. F. 1898. Die Passaliden Dichotomisch Bearbeitet. Novitates Zoologicae, 5: 137-349.

Luederwaldt, H. 1931. Monographia dos Passalideos do Brasil (Col.). Revista do Museu Paulista, 17: 1-262.

Percheron, A. 1835. Monographie des Passales et des genres qui en ont été séparés. J.A. Mercklein, Paris.

Percheron, A. 1841. Révision critique et supplément a la monographie du genre Passale. Magazine de Zoologie, 1841: 1148.
Schuster, J. C. 1992. State of Larval Taxonomy with Description of New World Species. The Florida Entomologist, 75: 357-369.

Schuster, J. C. \& Reyes-Castillo, P. 1981. New World genera of Passalidae (Coleoptera): a revision of larvae. Anales de la Escuela Nacional de Ciencias Biológicas, 25: 79-116.

Upegui Vélez, C. A. 2008. Sinopsis del género Passalus Fabricius, 1792 en Venezuela (Coleoptera: Scarabaeoidea: Passalidae). Tesis Maestría en Entomología, Facultad de Agronomía, Universidad Central de Venezuela [Not publishing]. 